\title{
ŚREDNIOWIECZNY KULT ŚW. STANISŁAWA POZA GRANICAMI POLSKI (ZE SZCZEGÓLNYM UWZGLĘDNIENIEM EUROPY ŚRODKOWEJ)
}

\author{
Stanislava Kuzmová \\ Uniwersytet Komeńskiego w Bratysławie
}

\section{ABSTRACT \\ THE MEDIEVAL CULT OF ST. STANISLAUS BEYOND THE BORDERS OF POLAND (IN CENTRAL EUROPE)}

The cult of St. Stanislaus, Bishop of Krakow, had spread to some extent beyond Poland already in the Middle Ages. The article investigates the contexts in which the devotion to the newly canonized saint, who was gradually established as the patron saint of the Kingdom, appeared, especially in the neighbouring countries and in some isolated places further abroad, first in the period around the canonization in 1253, when the new saint and his relics stirred interest in the close regions, and also among rulers, who used its symbolic meaning. Various representations of the cult abroad - in liturgy, church dedications, preaching and hagiographic texts in circulation - are mapped and examined. The cult spread mainly through personal contacts and exchange, although it functioned mostly in limited space and time.

Key words: St. Stanislaus, martyr-bishop, liturgical cult, preaching, church dedications, relics.

Słowa kluczowe: św. Stanisław, biskup męczennik, kult liturgiczny, kaznodziejstwo, patrocinia, relikwie.

Kult św. Stanisława, chociaż przekroczył granice Polski, nigdy nie stał się ani powszechny, ani bardzo popularny w Europie. Pominę tu rozważania na temat rozwoju kultu na terenie Krakowa i na ziemiach polskich oraz na Śląsku, gdyż był on już przedmiotem wielu studiów, choć trzeba zaznaczyć, że wciąż wiele jest na tym polu do zrobienia. Także kult św. Stanisława poza granicami Polski był przedmiotem zainteresowania historyków ${ }^{1}$. W niniejszym artykule będę opierała się na istniejącej literaturze na interesujący nas temat, uzupełniając ją o wyniki własnych badań. Sku-

1 Przegląd miejsc kultu poza granicami Polski zob. zwłaszcza K. Dobrowolski, Kult św. Stanisława $w$ St. Florian $w$ średnich wiekach, „Rocznik Krakowski” 1923, t. 19, s. 116-133, zwłaszcza 
pię się przy tym przede wszystkim na śladach kultu św. Stanisława na Węgrzech, w Czechach i w innych sąsiednich krajach, a także w kilku miejscach jeszcze bardziej odległych od granic Królestwa Polskiego ${ }^{2}$. Historycy podejmujący badania nad kultem koncentrowali się głównie na jego politycznych i symbolicznych aspektach, których ślady da się wskazać także poza granicami Polski. Warto jednak zwrócić uwagę na inne sfery kultu św. Stanisława. W moim artykule pragnę ukazać ważne etapy jego rozwoju poza granicami kraju w okresie związanym z procesem kanonizacyjnym i po kanonizacji. Następnie przejdę do uwag na temat ośrodków kultu w krajach sąsiadujących z Polską. Postaram się też wskazać na świadectwa rozpowszechniania się kultu występujące $\mathrm{w}$ różnych typach źródeł: w przepisach liturgicznych, kalendarzach, patrociniach, zabytkach ikonograficznych, tekstach hagiograficznych i kazaniach.

\section{OKRES OKOŁOKANONIZACYJNY}

Istnieją w historiografii hipotezy, że kult polskiego biskupa mógł przekroczyć granice Polski jeszcze przed kanonizacją. Miał on dotrzeć na przykład do Czech, co zdawała się potwierdzać jedna z datacji wzmianki o św. Stanisławie w Żywocie błogosławionego Hroznaty ${ }^{3}$. Inna hipoteza wskazywała na Szwecję jako ośrodek przedkanonizacyjnego kultu świętego, czego dowodzić miała jedna $\mathrm{z}$ interpretacji wizerunku na chrzcielnicy z Tryde ${ }^{4}$. Obie te hipotezy zostały w obecnej historiografii słusznie zakwestionowane po badaniach źródłoznawczych wspomnianych zabytków. Pewnych dowodów na istnienie kultu św. Stanisława poza granicami Polski dostarcza nam II połowa XIII wieku. Nowy święty i wydarzenia, jakie towarzyszyły kanonizacji, budziły zainteresowanie w krajach sąsiadujących z Polską, zwłaszcza

s. 119-120; W. Schenk, Kult liturgiczny św. Stanisława biskupa na Ślasku w świetle średniowiecznych rękopisów liturgicznych, Lublin 1959, s. 32-33.

2 Niniejszy artykuł jest rozszerzoną wersją referatu przedstawionego w ramach panelu pt. „Panteon świętych patronów: Polska i jej sąsiedzi w średniowieczu” na II Kongresie Zagranicznych Badaczy Dziejów Polski w Krakowie w 2013 r. Wykorzystuję w nim wyniki moich badań z rozprawy doktorskiej, która ukazała się drukiem pod tytułem Preaching Saint Stanislaus: Medieval Sermons on St. Stanislaus of Cracow, His Image and Cult, Warszawa 2013. Pragnę podziękować prof. Krzysztofowi Ożogowi, organizatorowi tego panelu, za zaproszenie i za wszelką pomoc udzieloną przez niego w trakcie przygotowywania tekstu do druku.

3 Jerzy Rajman uważał że kult dotarł do Czech za sprawą kontaktów premonstrateńskich klasztorów; zob. J. Rajman, Przedkanonizacyjny kult św. Stanisława, „Nasza Przeszłość” 1993, t. 80, s. 43-45. Wcześniejsza datacja wzmianki o św. Stanisławie w Żywocie Hroznaty (Vita b. Hrosnatae mart. Ord. Praem. [w:] Acta Sanctorum [dalej cyt.: AA.SS.], Julii III, Antverpiae 1723, coll. 804-810; i Život blahoslaveného Hroznaty [w:] Fontes rerum Bohemicarum [dalej cyt.: FRB], ed. J. Emler, Pragae 1873, vol. 1, s. XXVII-XXX, 379) na czas przed kanonizacją została odrzucona przez Petra Kubína, zob. idem, Blahoslavený Hroznata - Kritickýživotopis, Praha 2000, s. 47-49.

${ }_{4}$ Na temat dyskusji o chrzcielnicy w Tryde, zob. np.: G. Labuda, Święty Stanisław. Biskup krakowski, patron polski. Śladami zabójstwa - męczeństwa - kanonizacji, Poznań 2000, s. 148-156; A. Rożnowska-Sadraei, Pater Patriae: The Cult of Saint Stanislaus and the Patronage of Polish Kings 1200-1455, Kraków 2008, s. 31-35. 
w Czechach i na Węgrzech. Kanonizacja papieska, której procedura właśnie wtedy przybierała ostateczny kształt w Kościele katolickim ${ }^{5}$, pozostawiła ślady kultu polskiego świętego także w Rzymie i Asyżu, gdzie miała miejsce główna uroczystość. W liturgii sprawowanej w bazylice Świętego Piotra i w kaplicy papieskiej w Rzymie święto św. Stanisława było obchodzone przez kilka dziesięcioleci XIII wieku. Zostało ono najpewniej wprowadzone przez papieża Urbana IV (1261-1264), który kilkakrotnie w latach 40. odwiedzał Polskę jako legat, a ponadto za czasów jego pontyfikatu do papieskiej kaplicy należało dwóch kanoników krakowskich ${ }^{6}$. W Asyżu z kolei, w jednej z kaplic w dolnej bazylice, powstał ołtarz dedykowany św. Stanisławowi ${ }^{7}$. Kaplicę tę zdobiły powstałe w latach 30. i 40. XIV wieku freski jednego $\mathrm{z}$ uczniów Giotta, przedstawiające sceny $\mathrm{z}$ legendy świętego ${ }^{8}$. Były one zapewne bardziej pamiątką po uroczystej kanonizacji odwiedzaną przez polskich pielgrzymów, niż miejscem żywego kultu i regularnie sprawowanych nabożeństw.

Świadectwem kultu św. Stanisława w Europie Środkowej są wzmianki w zbiorze jego mirakulów mówiące o pielgrzymach udających się do Krakowa w okresie okołokanonizacyjnym: o pielgrzymie z Czech, który w Krakowie doznał cudu za sprawą świętego biskupa ${ }^{9}$, i o węgierskim chłopcu, który za przyczyną męczennika

5 Na temat ewolucji procedury kanonizacyjnej zob. A. Vauchez, Sainthood in the Later Middle Ages, Cambridge 1997, s. 22-84; R. Paciocco, Canonizzazioni e culto dei santi nella christianitas (1198-1302), Assisi 2006, s. 3-134.

6 Stwierdził to Pierre David na podstawie tzw. Rzymskiego legendarium (powstałego w latach 1254-1255, z dodatkami z lat 1261-1264), w którego kalendarzu pod 11 kwietnia figurowało święto męczeństwa św. Stanisława, a tekst lekcji brewiarzowych został zaczerpnięty z bulli kanonizacyjnej, zob.: Bibliothèque Nationale w Paryżu rkps: Lat. 755, ff. 214-215; P. David, Un légendier romain du temps d'Innocent IV et d'Urbain IV, Paris 1936, s. 11, 17-20, transkrypcja na s. 21-25; S. Kuzmová, Preaching Saint Stanislaus: Medieval Sermons on St. Stanislaus of Cracow, His Image and Cult, Warszawa 2013, s. 66, 110-111. O liturgicznym kulcie w Rzymie wspomina też W. Schenk, zob. op. cit., s. 33.

7 O powstaniu ołtarza zob.: Vita sancti Stanislai Cracoviensis episcopi (Vita maior) auctore fratre Vincentio de ordine fratrum praedicatorum, wyd. W. Kętrzyński [dalej cyt.: Vita maior] [w:] Monumenta Poloniae Historica [dalej cyt.: MPH], t. 4, Lwów 1884, s. 437. O bulli papieskiej z 26 stycznia 1256 r. nadającej odpusty dla odwiedzających w oktawę święta ołtarz zbudowany przez biskupa i kapitułę krakowską z relikwiami świętego zob.: Bullarium Poloniae, ed. I. Sułkowska-Kuraś, S. Kuraś, [t.] 1: 1000-1342, Romae 1982, nr 593; edycja bulli w: Bullarium Franciscanum Romanorum pontificum constitutiones, epistolas, ac diplomata continens tribus ordinibus Minorum, Clarissarum, et Poenitentium a seraphico patriarcha sancto Francisco institutis concessa ab illorum exordio ad nostra usque tempora, t. 2, ed. J.H. Sbaralea, Romae 1761 (Ed. Porziuncola 1983), nr 155, 111-112. Późniejszy opis kaplicy u J. Długosza: Vita sanctissimi Stanislai, ed. I. Polkowski, Ż. Pauli [w:] Joannis Dlugossii Senioris Canonici Cracoviensis Opera omnia, t. 1, Kraków 1887, s. 142.

8 Małgorzata Kochanowska-Reiche uważa, że freski zostały sporządzane w związku z obecnością polskiej delegacji na kapitule generalnej zakonu franciszkanów w Asyżu w 1334 r., zob.: eadem, Ikonografia kanonizacyjna św. Stanistawa biskupa, „Biuletyn Historii Sztuki i Kultury” 1987, t. 49, nr 1-2, 78-79. Zob. także M. Plezia, Dookoła sprawy świętego Stanisława, Bydgoszcz 1999, s. 45-48; S. Kuzmová, Preaching Saint Stanislaus..., s. 75 (o freskach), 111.

9 Przedwoj z Czech, uderzony piorunem, został porażony i ogłuszony, a następnie uzdrowiony za wstawiennictwem św. Stanisława, którego on nie znał, bowiem biskup męczennik nie był jeszcze kanonizowany. Święty ukazał się Przedwojowi we śnie i nakazał mu pielgrzymkę do Krakowa; Miracula sancti Stanislai, wyd. W. Kętrzyński [dalej cyt.: Miracula] [w:] MPH, 4, s. 317-318 (art. 44), i Vita maior, III 22, s. 408-409. 
został przywrócony do życia ${ }^{10}$. Świadectwem ruchu pątniczego są też znaki pielgrzymie $\mathrm{z}$ wizerunkiem świętego znalezione na Morawach i w Czechach ${ }^{11}$. Ważną rolę odegrały uroczystości pokanonizacyjne, które miały miejsce w Krakowie w 1254 roku, a w których uczestniczyli liczni przedstawiciele hierarchii kościelnej i świeccy dostojnicy, także spoza granic Polski ${ }^{12}$. Wtedy rozdawano różnym instytucjom kościelnym relikwie świętego. Była to zapewne jedna z dróg, którą wiadomość o nowym świętym i jego kult dotarły między innymi na Węgry (przede wszystkim w rejony Spisza i Szarysza) oraz do Czech.

Wkrótce po kanonizacji kult św. Stanisława nabrał także istotnego wymiaru politycznego. Już Vita maior ściśle złączyła postać biskupa męczennika z historią Polski. W świetle tego dzieła kryzys państwa i jego podział były karą za śmierć biskupa $\mathrm{z}$ ręki króla Bolesława. To także w tym tekście po raz pierwszy idea renovatio regni została powiązana ze świętym biskupem męczennikiem przez podobieństwo z cudem zrośnięcia się ciała świętego ${ }^{13}$. Polityczne treści nadawały kultowi nie tylko dzielnicowy, ale i ogólnopolski charakter, otwierając mu zarazem drogę do tego, by mógł odgrywać pewną symboliczną rolę w stosunkach międzypaństwowych. W średniowieczu dary relikwii patronów były wykorzystywane wielokrotnie w stosunkach dyplomatycznych między władcami i państwami ${ }^{14}$. Biskup krakowski Prandota przekazał relikwię - ramię świętego - Przemysłowi Otokarowi II. W liście skierowanym do biskupa krakowskiego, dziękując za jej przesłanie, czeski król przedstawił siebie jako gorliwego czciciela św. Stanisława, który pomógł Czechom w wyprawie na Prusy ${ }^{15}$.

10 Miracula, art. XXXIV, s. 310; Vita maior, III/10, s. 402-403. Zapiska w Miracula mówi o tym, że ojciec chłopca nazywany był Węgrem, ale nie wspomina jednak nic o jego pochodzeniu czy pielgrzymce, natomiast Vita maior dodaje informację o powrocie rodziny na Węgry.

11 Odkryto je w Pradze, Hradec Králové i Černá Hora koło Brna. A. Rożnow ska-Sadraei, Pater Patriae..., s. 87-95, opisuje obiekty i podaje bibliografię, zob. też: W. Mischke, Pierwotny schemat ikonograficzny przedstawiania św. Stanisława ze Szczepanowa: Krakowski znak pielgrzymi z Czech i Moraw, „Ciechanowskie Studia Muzealne” 1990, t. 2, s. 37-68. O znaku pielgrzymim i o jego ideowym oraz politycznym znaczeniu zob. W. Drelicharz, Idea zjednoczenia królestwa w średniowiecznym dziejopisarstwie polskim, Kraków 2012, s. 129-150.

12 Opis uroczystości podają m.in.: J. Długosz, Vita, s. 148-149; Katalog V biskupów krakowskich, wyd. J. Szymański [w:] „Monumenta Poloniae Historica”, Series Nova [dalej cyt.: MPH SN], t. 10/2, Warszawa 1974, s. 94-95; Katalog IV biskupów krakowskich [w:] ibidem, s. 63; Kronika wielkopolska, wyd. B. Kürbis, MPH SN, t. 8, Warszawa 1970, s. 101.

13 Vita maior, s. 390-393. Problem ten został dobrze omówiony w literaturze, zob. J. Banaszkiewicz, ,Sicut corpus sancti Stanislai Deus reintegravit...”, „Novum” 1979, nr 4-5, s. 213-218; P. W ęc ow ski, Strata korony królewskiej po śmierci św. Stanisława w opinii pisarzy późnego średniowiecza [w:] Christianitas Romana. Studia ofiarowane prof. Romanowi Michałowskiemu, red. K. Skwierczyński et al., Warszawa 2009, s. 274-299; W. Drelicharz, op. cit., s. 150-199. Na temat politycznych funkcji kultu zob. W. Mrozowicz, Die politische Rolle des Kultes des hl. Adalbert, Stanislaus und der hl. Hedwig im Polen des 13. Jahrhunderts [w:] Fonctions sociales et politiques du culte des saints dans les sociétés de rite grec et latin au Moyen Âge et à l'epoque moderne : Approche comparative, éd. M. Derwich, M. Dmitriev, Wrocław 1999, s. 111-125.

14 M. Starnawska, Świętych życie po życiu. Relikwie w kulturze religijnej na ziemiach polskich w średniowieczu, Warszawa 2008, s. 557 i nast.

15 List Przemysła Ottokara II do Prandoty z 19 lipca 1255 r. z podziękowaniem za relikwie: Codex diplomaticus et epistolaris regni Bohemiae, vol. 5/1, ed. J. Šebánek, S. Dušková, Praha 1974, nr 48, 
Taka retoryka miała polityczne uzasadnienie i zapewne jej celem było skłonienie biskupa do interwencji u księcia Bolesława na rzecz przywrócenia pokoju i wymiany jeńców po niedawnych polsko-węgierskich atakach na Morawy, prowadzonych razem z Danielem, władcą Rusi Halickiej ${ }^{16}$. Późniejsze źródła (Długosz, który czerpał z Kroniki Pulkavy, katalogu biskupów krakowskich, wybranych czeskich roczników i Kroniki Jana Marignolego) wspominają o prośbie Przemysła Otokara II i ofiarowaniu mu relikwii, ale nic nie mówią o jego politycznej motywacji i łączą je wprost $\mathrm{z}$ kanonizacją św. Stanisława. Niektóre z nich opisują procesję, która powitała w Pradze wysłanników z relikwiami ${ }^{17}$.

Dla rozwoju kultu św. Stanisława na Węgrzech kluczowe znaczenie miała najpewniej wizyta w Krakowie Stefana V, brata Kingi, żony Bolesława Wstydliwego. Jej przebieg znamy dzięki Kronice Dzierzwy. Odnotowano w niej, że Stefan przybył do Krakowa w 1268 roku, aby „nawiedzić progi świętego Stanisława i spotkać się z Bolesławem”. Kronikarz dodał, że wspomniany król zawarł pokój i przymierze z księciem Bolesławem, które zaprzysiężono na relikwię Drzewa Krzyża Pańskiego ${ }^{18}$. Również kilka innych źródeł wspomina o tej wizycie, datując ją na 1270 rok, a zatem na okres po śmierci króla Beli IV ${ }^{19}$. Podobnie jak w przypadku Przemysła Ottokara II także cześć dla świętego biskupa okazywana przez króla węgierskiego miała swój polityczny podtekst. Patrocinium św. Stanisława w zniszczonym obecnie klasztorze augustiańskim w Wielkim Szaryszu (Vel'ký Šariš), miejscu rezydencji Stefana V, mogło powstać po wizycie króla w Krakowie, gdy przywiózł relikwie świętego. Po raz

s. 99-101 (wcześniejsza edycja w: Kodeks dyplomatyczny Katedry Krakowskiej św. Wacława, cz. 1, wyd. F. Piekosiński, Kraków 1874 [dalej cyt.: KDKK], nr 44).

16 Z. Jakubowski, Polityczne i kulturowe aspekty kultu biskupa krakowskiego Stanisława w Polsce i Czechach w średniowieczu, Częstochowa 1988, s. 102-109; A. Barciak, Czechy a ziemie poludniowej Polski w XIII oraz poczatkach XIV w. Polityczno-ideologiczne problemy ekspansji czeskiej na ziemie potudniowej Polski, Katowice 1992, s. 93-97; M. Starnawska, Świętych życie po życiu..., s. 86, 329, 558-559; a ostatnio W. Drelicharz, op. cit., s. 151-157; zob. też: S. Kuzmová, Preaching Saint Stanislaus..., s. 102-103.

17 Ioannis Dlugossii Annales seu Cronicae incliti Regni Poloniae, liber 7-8, ed. D. Turkowska et al., Varsaviae 1975, s. 94. Kronika Marignolova, ed. J. Emler [w:] FRB, vol. 3, Praha 1878, s. 565. Kronika Pulkavova, ed. J. Emler, J. Gebauer [w:] FRB, vol. 5, Praha 1893, s. 300. O procesji witającej relikwie w Pradze (22 października 1253) zob. także Letopisy české, ed. J. Emler [w:] FRB, vol. 2, Praha 1874, s. 291-292. O darze relikwii Katalog IV biskupów krakowskich [w:] MPH SN 10/2, s. 63; Katalog V biskupów krakowskich [w:] MPH SN 10/2, s. 95. O dalszych losach relikwii św. Stanisława w Pradze zob. niżej, przypis 30 .

18 „Stephanus, rex Ungarie venit Cracoviam visitare limina sancti Stanislai, et ut videret ducem Boleslaum sororium suum, utpote qui habebat dominam Kyngam germanam suam. Fecit quoque predictus rex pacem et concordiam cum Boleslao perpetuam prestito super crucem de ligno iuramento, hoc eciam fecit idem dux et omnes barones utriusque partis". Kronika Dzierzwy, wyd. K. Pawłowski, MPH SN, t. 15 , Kraków 2013, s. 80.

19 Rocznik Traski, wyd. A. Bielowski [w:] MPH, t. 2, Lwów 1872, s. 841; I. Dlugossii Annales, lb. 7-8, s. 214-215. Więcej na temat politycznych interesów i motywacji Stefana V, zob.: M. Homza, Svätá Kunigunda a Spǐ̌ [w:] Terra Scepusiensis: Stav bádania o dejinách Spiša, red. R. Gładkiewicz, M. Homza, Levoča-Wrocław 2003, s. 382, 386; idem, Včasnostredoveké dejiny Spiša [w:] Historia Scepusii, vol. 1, red. M. Homza, S.A. Sroka, Bratislava-Kraków 2009, s. 154, 204. 
pierwszy zostało ono potwierdzone źródłowo w $1274 \mathrm{roku}^{20}$. Podobnie nieistniejące dziś patrocinium w Miloj, odnotowane w źródłach w 1402 roku (choć pochodziło ono zapewne $\mathrm{z}$ wcześniejszego okresu), zostało nadane najpewniej dzięki panom z Hrhov/Görgey, którzy byli bliskimi współpracownikami Stefana V i prawdopodobnie towarzyszyli mu w podróży do Krakowa ${ }^{21}$. Niewątpliwie działalność świętej Kingi, ściśle związanej z franciszkanami, mogła się przyczynić do rozprzestrzeniania kultu, tym bardziej że wspierała ona starania o kanonizację biskupa męczennika była panią ziemi sądeckiej i poprzez kontakty ze szlachtą spiską oraz swoją politykę donacyjną wraz z ojcem Belą IV i bratem Stefanem V, zasiadającymi na tronie węgierskim, współdziałała w podtrzymaniu zainteresowania kultem świętego ${ }^{22}$.

Znacznie trudniej stwierdzić rozwój kultu św. Stanisława w związku z jego kanonizacją na ziemiach położonych na wschód od Polski. Warto przypomnieć, że bulla papieska z 26 maja 1252 roku, nakładająca na franciszkanina Jakuba z Velletri obowiązek ponownego zbadania cudów na potrzeby procesu kanonizacyjnego biskupa Stanisława, polecała mu między innymi sprawdzenie, jak bardzo diecezja krakowska jest oddalona od schizmatyckiej Rusi ${ }^{23}$. W historiografii powszechnie znany jest fakt, że papieska zgoda na kanonizację była powiązana z planami misyjnymi na wschodzie, w których franciszkanie i dominikanie odgrywali ważną rolę. Ich realizacji miało także służyć pozyskanie przez Stolicę Apostolską Daniela Halickiego ${ }^{24}$. Święty Stanisław pojawia się ponownie w kontekście misji wschodniej w latach 80 . $\mathrm{XV}$ wieku, kiedy to bernardyn mistrz Stanisław ze Szłap sporządził ciekawą przeróbkę Długoszowego Żywota św. Stanisława ${ }^{25}$. Według Prologu autor przedłożył ją kapitule zakonu, proponując wykorzystywanie Żywota jako pomocy dla kaznodziejów działających na terenie Litwy, nie tylko wśród katolików, ale i wśród schizmatyków. Ponadto przypomniał on o franciszkańskich zasługach w staraniach o kanonizację biskupa Stanisława i owocach jego kultu w działalności zakonu między „schizmatykami, Rusinami, Wałachami i na sąsiednich terenach” oraz w Wielkim Księstwie

20 J. Hudák, Patrociniá na Slovensku, Bratislava 1984, s. 337; A. Mező, Patrocíniumok a középkori Magyarországon, Budapest 2003, s. 395-396.

${ }_{21}$ J. Hudák, op. cit., s. 337; A. Mező, op. cit., s. 395; M. Homza, Včasnostredoveké dejiny Spiša, s. $182,204-205.7$

22 M. Homza, Svätá Kunigunda a Spiš, s. 385, 395-398; idem, Včasnostredoveké dejiny Spiša, s. 155-171 i passim.

23 KDKK 1, nr 33, s. 41

24 Zob. np.: W. Abraham, Powstanie organizacji Kościoła tacińskiego na Rusi, Lwów 1904, s. 117, 141 i passim; A. Witkowska, The thirteenth-century miracula of St. Stanislaus, Bishop of Krakow [w:] Procés de canonisation au Moyen Âge: Aspects juridiques et religieux, éd. G. Klaniczay, Rome 2004, s. 152; D.A. Dekański, Początki zakonu dominikanów prowincji polsko-czeskiej, Gdańsk 1999, s. 124 i nast.

25 Dzieło zachowało się w rękopisach Biblioteki Jagiellońskiej (dalej cyt.: BJ), 4915, f. 350r-367r, i Bibliotece XX Czartoryskich w Krakowie (dalej cyt.: BCzart), 3793 II, s. 1449-1478 (z Prologiem). Szerzej o tym S. Kuzmová, Preaching Saint Stanislaus, s. 58, 165-166, 177; Appendix 1, Register of Sermons, Sermon Material nr LXXVIII. Na temat tego Żywota w kontekście hagiografii dotyczącej św. Stanisława mówiłam już w innym miejscu, S. Kuzmová, Kazania o św. Stanisławie a hagiografia [w:] Kaznodziejstwo średniowieczne. Teksty, atrybucje, audytorium. Polska na tle Europy, red. K. Bracha, A. Dąbrówka, Warszawa 2014 („Colloquia Mediaevalia Praedicatoria”, t. 1), s. 75-77. 
Litewskim ${ }^{26}$. Kult św. Stanisława na wschód od dzisiejszych granic Polski, zwłaszcza na historycznych terenach Rusi Halicko-Włodzimierskiej i Wielkiego Księstwa Litewskiego, nie był przedmiotem gruntownych badań. Byłby to temat godny bliższego zainteresowania, jeśli tylko zachowane źródła (wezwania kościołów, przepisy liturgiczne etc.) pozwoliłyby na takie badania. Historycy, którzy poruszali ten problem, zazwyczaj uciekali się do uproszczeń, stwierdzając, że kult św. Stanisława rozwijał się na ziemiach leżących na wschód od dzisiejszych granic Polski, na potwierdzanie tej konstatacji nie przytaczali jednak żadnych konkretnych źródeł dokumentujących jego przejawy.

\section{OKRES POKANONIZACYJNY}

\section{Kontakty dynastyczne i polityczne}

Nie tylko w okresie około kanonizacji, ale i po XIII wieku w krajach sąsiadujących z Polską - przede wszystkim w królestwach Czech i Węgier - powiązania i kontakty z polskimi książętami, a następnie królami przyczyniły się do rozpowszechniania kultu biskupa, który stał się głównym patronem Piastów panujących w Krakowie, a potem całego Królestwa Polskiego. Ograniczę się tu do kilku niezbędnych uwag. Dwie kolejne żony Karola Roberta Węgierskiego, Maria i Elżbieta Łokietkówna (wraz z licznymi Polakami w ich otoczeniu działającymi wówczas na Węgrzech), przeszczepiały na węgierski grunt polskie tradycje i pobożność związaną ze świętym patronem królestwa. Brat Marii, Bolesław, był arcybiskupem Ostrzyhomia w latach 1321-1328, a następnie w latach 1334-1344 biskupem Veszprému i królewskim kanclerzem $^{27}$. Objęcie polskiego tronu przez Ludwika Węgierskiego i regencja jego matki Elżbiety w Polsce jeszcze bardziej zacieśniły te relacje. Obecność legendy obrazowej, cyklu narracyjnego o św. Stanisławie w Wegierskim Legendarium Andegaweńskim jest odzwierciedleniem miejsca, jakie polski święty zajmował w panteonie patronów dynastii andegaweńskiej ${ }^{28}$.

Z kolei w Czechach za panowania Jana Luksemburskiego i Karola IV włączono do Korony św. Wacława większość księstw śląskich, ale biskupstwo wrocławskie pozostało nadal w gnieźnieńskiej prowincji kościelnej mimo luksemburskich

26 BCzart rkps 3793 II, s. 1449-1450. Prologu autora brakuje w drugim egzemplarzu.

27 S. Sroka, Z dziejów stosunków polsko-węgierskich w późnym średniowieczu, Kraków 1995, s. $33,47-48$.

28 Opis cyklu stanisławowego w: M. Kochanowska-Reiche, Najstarsze cykle narracyjne z legendy św. Stanisława biskupa, „Ikonotheka. Prace Instytutu Historii Sztuki Uniwersytetu Warszawskiego" 1991, t. 3, s. 39-47; E. Śn ieżyńs ka-S tolot, Ze studiów nad ikonografią legendy św. Stanisława biskupa, „Folia Historiae Artium” 1972, t. 8, s. 162-166; B.Z. Szakács, A Magyar Anjou Legendárium képi rendszerei, Budapest 2006, s. 98-99; S. Kuzmová, Preaching Saint Stanislaus..., s. 77-80, 83. Na temat legendarium zob. m.in.: G. Klaniczay, Holy Rulers and Blessed Princesses: Dynastic Cults in Medieval Central Europe, Cambridge 2002, s. 356-362. 
zabiegów o podporządkowanie go arcybiskupstwu praskiemu. W 1363 roku cesarz Karol IV, znany kolekcjoner relikwii, miał otrzymać relikwie św. Stanisława od Kazimierza Wielkiego ${ }^{29}$. Podobnie jak w czasach kanonizacyjnych, podarowanie relikwii było częścią rytuału spotkania obu panujących. Przekazane wówczas cesarzowi relikwie znajdowały się później w Pradze $^{30}$. Karol IV ufundował augustiański konwent i kościół św. św. Wacława, Stanisława i Doroty we Wrocławiu, łącząc w jednym wezwaniu patrona Czech z patronem Królestwa Polskiego i św. Dorotą, którą darzył osobistym nabożeństwem ${ }^{31}$.

Bliskie związki między Polską, Czechami i Węgrami znalazły swoją kontynuację w XV wieku. Jak pokazuje S.A. Sroka, za panowania Zygmunta Luksemburskiego, w pierwszej połowie XV wieku, obecność polska na Węgrzech przybrała jednak nowy charakter - kontakty dynastyczne uległy znacznemu ograniczeniu, natomiast karierę robili liczni przedstawiciele polskiej szlachty i duchowieństwa, obejmujący, podobnie jak to miało miejsce za czasów Elżbiety Łokietkówny, liczne urzędy

29 W. Schenk, op. cit., s. 23; De s. Stanislao martyre episcopo in Polonia [Wstęp do: Vita auctore Joanne Longino seu Dlugosso] [w:] AA.SS., Maii II (Dies 7), Antwerpiae 1680, facsimile reprint Turnhout 1968, s. 199-200. Kult św. Stanisława na Śląsku, który został pominięty w niniejszym artykule, co wynika z faktu jego przynależności do gnieźnieńskiej prowincji kościelnej, był przedmiotem szczegółowych studiów, zob.: W. Schenk, op. cit.; K. Dola, Kult świętego Stanistawa biskupa i męczennika a tradycje polskie na Śląsku, „Studia Teologiczno-Historyczne Śląska Opolskiego” 1979, t. 7, s. 245-260; Kult świętego Stanisława na Ślasku (1253-2003), red. A. Pobóg-Lenartowicz, Opole 2004; S. Kuzmová, Preaching Saint Stanislaus..., s. 95, 98-100, 123. Na tym terenie kult świętego biskupa również miał pewien wymiar polityczny, bowiem, według stwierdzenia K. Doli, reprezentował „tradycje polskie na Śląsku”, który był przedmiotem polsko-czeskich zatargów.

30 Dalsze losy relikwii przechowywanych w Pradze w katedrze św. Wita są bardzo ciekawe. Kapituła praska przekazała w 1434 r. część relikwii do Pilzna; De s. Stanislao martyre episcopo in Polonia [Wstęp do: Vita auctore Joanne Longino seu Dlugosso] [w:] AA.SS., Maii II (Dies 7), s. 200. Rocznica zwycięstwa nad taborytami zbiegała się tam ze świętem Stanisława i była tam prawdopodobnie regularnie obchodzona. Inwentarz z 1476 r. wspomina relikwiarz - tumbę z relikwiami św. Stanisława razem z cząstkami innych świętych - wśród obiektów zwróconych z Pilzna; A. Podlaha, E. Šittler, Chrámový poklad u sv. Vita v Praze, jeho dějiny a popis, Praha 1903, s. 221, LXXV. O relikwiarzu wspomina też Z. Jakubowski, op. cit., s. 69. Pisze on także o ołtarzu św. Stanisława i św. Oswalda z relikwiami polskiego świętego istniejącym w 1259 r. i potwierdzonym w 1654 r., zob. ibidem, s. 65. W niespokojnych czasach husyckich i późniejszym okresie kapitula praska, a wraz z nią relikwie i inne skarby wielokrotnie zmieniały miejsce pobytu. Późniejsze inwentarze praskich relikwii wspominają relikwie św. Stanisława: ramię otrzymane w 1253 r., digitus - dar Kazimierza dla Karola IV z 1363 r., oraz ząb z katalogów $\mathrm{z}$ Karlštejna; Catalogi SS. Reliquiarum quae in sacra metropolitana ecclesia Pragensi asservantur, annis 1673, 1691 et 1721 typis editi, ed. A. Podlaha [w:] Editiones archivii et bibliothecae S. F. Metropolitani capituli Pragensis Opus XXIV, Pragae 1931, s. 56, 103, 143, 148, 159. Relikwia zęba Stanisława znajduje się na liście relikwii karlštejnskich dołączonych do skarbu św. Wita w Pradze w 1645 r.; A. Podlaha, E. Šittler, op. cit., s. 117. Siedemnastowieczny opis kultu relikwii w katedrze wzmiankuje ołtarz Zwiastowania, św. Tomasza i św. Stanisława, dedykowany 22 kwietnia w kaplicy Sternberskiej; Wence slau s Coelestinus a Blumenberg, Devota ac debita veneratio ad sanctos patronos in sacra metropolitana ecclesia Pragensi. 1654, ed. A. Podlah a [w:] Editiones archivii et bibliothecae S. F. Metropolitani capituli Pragensis Opus XXIV, s. 18-19.

31 W. Schenk, op. cit., s. 23; H.J. Sobeczko, Liturgia Katedry Wroctawskiej wedlug przedtrydenckiego „Liber Ordinarius” z 1563 roku (Opole, Archiwum Diecezjalne, rkps nr M 1), Opole 1993, s. 186. 
i beneficja ${ }^{32}$. Polscy duchowni niewątpliwie odegrali ważną rolę w upowszechnianiu kultu świętego. Świadectwem tego może być między innymi liturgia i obieg tekstów pastoralnych o św. Stanisławie, o których będę pisała nieco dalej. Na Spiszu istotne znaczenie miał zastaw trzynastu spiskich miast polskiemu królowi przez Zygmunta Luksemburskiego, które pozostały przy Polsce przez ponad trzy i pół stulecia. W jego wyniku w regionie, gdzie i tak już wcześniej z racji bliskiego sąsiedztwa istniały liczne kontakty osobiste, społeczne i ekonomiczne, polskie wpływy nasiliły się jeszcze bardziej. Na Spiszu dochodziło też do sporów jurysdykcyjnych między gnieźnieńską prowincją kościelną a metropolią ostrzyhomską ${ }^{33}$.

W XV i na początku XVI wieku kontakty między Polską a Węgrami i Czechami podtrzymywane były przez dynastię jagiellońską, która rządziła w tych królestwach, a także dzięki związkom między poszczególnymi rodami magnackimi ${ }^{34}$. Już wcześniej, za czasów Piastów i Andegawenów, św. Stanisław był jednym z patronów Królestwa Polskiego, dlatego też Jagiellonowie, jako nowa, a nadto obca dynastia, starali się nawiązywać do rodzimego świętego patrona. Unia polsko-litewska i wstąpienie na tron polski Władysława Jagiełły było drugą obok kanonizacji ważną okolicznością i inspiracją dla rozwoju kultu św. Stanisława na terenach Wielkiego Księstwa Litewskiego. Ufundowaną w 1387 roku katedrę w Wilnie Jagiełło dedykował św. Stanisławowi i św. Władysławowi ${ }^{35}$. Istotny wkład w nadawanie kultowi św. Stanisława wymiaru politycznego miał za panowania pierwszych Jagiellonów biskup krakowski Zbigniew Oleśnicki. Owocem tych zabiegów są zarówno przejawy indywidualnej pobożności poszczególnych Jagiellonów, jak i przede wszystkim rytuały oraz elementy oficjalnego ceremoniału królewskiego o charakterze reprezentatywnym, symbolicznym i legitymizacyjnym. Zaliczyć do nich można: rytuał koronacyjny przy grobie św. Stanisława i przedkoronacyjną pielgrzymkę pokutną na Skałkę, do miejsca męczeństwa biskupa (pojawia się ona w ordo coronandi z 1434 roku), zwyczaj składania sztandarów w katedrze przy jego grobie, który stał się ara patriae, udział w procesjach i uroczystościach liturgicznych, fundacje relikwiarzy, a także ikonograficzne wyobrażenia i dzieła literackie tworzone na dworze. W pan-

32 S.A. Sroka, Polacy na Wegrzech za panowania Zygmunta Luksemburskiego, 1387-1437, Kraków 2001.

33 Podtrzymywanie kultu św. Stanisława w tych okolicznościach mogło być w niektórych przypadkach manifestacją polityczną; na przykład w Spišskiej Sobocie, gdzie polski święty znajdował się wraz z innymi świętymi na ołtarzu obok głównego patrona kościoła; zob. przypis 49. Na temat zastawu spiskich miast istnieje bogata literatura, zob. np. J. Kurtyka, Starostwo spiskie (1412-1769/70) [w:] Terra Scepusiensis..., s. 487-533.

${ }_{34}$ Zob. np. S.A. Sroka, Piastówny na Węgrzech w dobie Jagiellonów (1490-1526) [w:] Ecclesiacultura-potestas, red. P. Kras et al., Kraków 2006, s. 559-568.

35 Codex diplomaticus Ecclesiae Cathedralis necnon Dioeceseos Vilnensis, vol. 1: 1387-1507, wyd. J. Fijałek, W. Semkowicz, Kraków 1948, nr 1, s. 4: dokument wydany w Wilnie 17 lutego, 1387. Długosz także wspomina tę dedykację, zob. J. Długosz, Vita ..., s. 149. O fundacjach jagiellońskich, które wprowadziły na tereny wschodnie kult św. Stanisława, pisze U. Borkowska, The Jagiellonians as Founders of Ecclesiastical Institutions in the Grand Duchy of Lithuania and Poland [w:] Die Jagiellonen. Kunst und Kultur einer europäischen Dynastie an der Wende zur Neuzeit, Hrsg. D. Popp, R. Suckale, Nürnberg 2002, s. 128. 
teonie polskich świętych patronów to św. Stanisław w sposób najpełniejszy zdawał się wyrażać idee państwowe. Kwestia ta była przedmiotem zainteresowań historiografii dotyczącej dziejów Polski ${ }^{36}$. Kulty patronów państwowych niosły ze sobą treści symboliczne, które były wykorzystywane także w prezentowaniu dynastii poza granicami kraju oraz w legitymizacji jej władzy na nowych terenach ${ }^{37}$. Literatura pokazuje jak Jagiellonowie adaptowali kulty rodzimych patronów w Czechach i na Węgrzech ${ }^{38}$, odtwarzając panteon patronów. A. Rożnowska-Sadraei podkreśla brak promocji polskich świętych po uzyskaniu innych tronów przez Jagiellonów, którzy raczej popierali rodzime kulty w nowych krajach. Niestety temat „eksportu” polskich świętych przez monarchów jagiellońskich, jeśli w ogóle miał miejsce, wciąż pozostaje obszarem domagającym się dokładniejszego zbadania ${ }^{39}$.

36 Na temat stosunku Jagiellonów do kultu św. Stanisława zob. np.: U. Borkowska, Królewskie modlitewniki. Studium z kultury religijnej epoki Jagiellonów (XV i poczatek XVI wieku), Lublin 1999, s. 210-243; eadem, Dynastia Jagiellonów w Polsce, Warszawa 2011, s. 464-469; P. Cross1ey, Ara Patriae: St Stanislaus, the Jagiellonians and the Coronation Ordinal for Krakow Cathedral [w:] Künstlerische Wechselwirkungen in Mitteleuropa, Hrsg. J. Fajt, M. Horsch, Ostfildern 2005 („,Studia Jagiellonica Lipsiensia”, 1), s. 103-123; Z. Piech, Darstellungen des heiligen Stanislaus als Schutzheiligen des Herrschers, des Staates und der Dynastie der Jagiellonen [w:] Fonctions sociales et politiques du culte des saints dans les sociétés de rite grec et latin au Moyen Âge et à l'epoque moderne : Approche comparative, red. M. Derwich, M. Dmitriev, Wrocław 1999, s. 125-159; M. Walczak, The Jagiellonian Saints: Some Political, National and Ecclesiastical Aspects of Artistic Propaganda in Jagiellonian Poland [w:] Die Jagiellonen. Kunst und Kultur..., s. 139-149; A. Rożnowska-Sadraei, Pater patriae..., s. 291-391 (do roku 1450); eadem, Jagiellonians and the Internationalisation of National Saints [w:] Image, Memory and Devotion: Liber Amicorum Paul Crossley, ed. Z. Opacić, A. Timmermam, Turnhout 2011, s. 265-274.

37 To pokazuje na przykładzie Andegawenów i Luksemburczyków G. Klaniczay, Holy Rulers..., s. 295-394; na analogiczne postępowanie Jagiellonów zwraca uwagę M.R. Pauk, Święci patroni a średniowieczne wspólnoty polityczne w Europie Środkowej [w:] Sacrum. Obraz i funkcja w spoleczeństwie średniowiecznym, red. J. Pysiak, A. Pieniądz-Skrzypczak, Warszawa 2005, s. 248.

38 W Czechach Jagiellonowie wspierali kult św. Wacława poprzez odnowienie zniszczonych relikwiarzy i fundacje, zob.: U. Borkowska, Dynastia Jagiellonów..., s. 469-470; A. Rożnowska-Sadraei, Jagiellonians and the Internationalisation of National Saints, s. 272-274. Kult innego patrona polskiego, Wojciecha, którego treści łączyły Polskę, Czechy i Węgry, był użyteczny w Polsce do wyrażania symbolicznych wątków podczas zabiegów Kazimierza Jagiellończyka o odzyskanie tronów sąsiednich królestw dla swoich synów; uwagi na ten temat zob. Ł. Walczy, Kazanie Jana ze Stupczy $o$ św. Wojciechu - przyczynek do dziejów ideologii państwowej w drugiej połowie XV wieku, „Nasza Przeszłość" 1992, t. 77, s. 261-271. Podobnie kazanie zapisane przez Jana z Dąbrówki o Wojciechu, które wspomina Stanisława, zob. S. Kuzmová, Preaching Saint Stanislaus..., s. 293-295.

39 A. Rożnowska-Sadrae i, Jagiellonians and the Internationalisation of National Saints, s. 274. Znany jest np. nagrobek Bony Sforzy w kaplicy w Neapolu z 1534 r. z wizerunkiem św. Stanisława i innych polskich świętych, których kult żona Jagiellona zawdzięczała Polsce, zob. M. Bogucka, Bona Sforza, Warszawa 1998, s. 215, 220; U. Borkowska, Królewskie modlitewniki..., s. 126-159. 


\section{PRZEJAWY KULTU}

\section{Liturgia i święta}

Jednym z najważniejszych wyrazów pokanonizacyjnego kultu św. Stanisława jest liturgia. Diecezje w Czechach i na Morawach wspominały św. Stanisława w liturgii, choć jego kult nie był tu tak rozbudowany jak w Polsce. Różne średniowieczne kalendarze od XIV do początku XVI wieku odnotowują święto męczeństwa św. Stanisława pod datą 8 maja jako festum fori w diecezji praskiej (w najwyższej randze) i ołomunieckiej (w randze drugiej co do ważności). Żadna $\mathrm{z}$ tych diecezji nie obchodziła święta translacji. Czeskie statuty synodalne nie wspominają o święcie św. Stanisława ${ }^{40}$.

Niektóre z węgierskich ksiąg liturgicznych, datowane na XIV i XV wiek, odnotowują święto św. Stanisława w swoich kalendarzach. Do takich ksiąg, poza tymi proweniencji polskiej i czeskiej, należą mszał kapituły kolegiackiej z Bratysławy z XIV i XV wieku, księgi liturgiczne z różnych kościołów węgierskich, zwłaszcza z północnej części kraju, pozostającej dziś w granicach Słowacji, niektóre księgi z Ostrzyhomia, brewiarze premonstratensów z Leles i Jasova. Wszystkie księgi liturgiczne, których kalendarze uwzględniają święto, odnotowują je pod datą 8 maja, a znacznie rzadziej wzmiankują święto translacji ( 27 września). Niektóre z tych ksiąg zawierają nawet proprium stanisławowe, zaś w dwóch brewiarzach znajduje się rymowane oficjum Dies adest celebris ${ }^{41}$. Trzeba zwrócić uwagę na fakt, że informacje dotyczące obchodów święta polskiego biskupa w Królestwie Węgier dostarczone przez H. Wąsowicza, W. Schenka i H. Grotefenda nie są dość jasne, a w wielu miejscach autorzy ci dopuścili się uproszczeń i uogólnień ${ }^{42}$. Jakie było zatem miejsce święta świętego Stanisława w węgierskiej tradycji liturgicznej? Węgierski badacz liturgii P. Radó nie wymienia go wśród świętych cieszących się szczególnym liturgicznym kultem na terenie Węgier ${ }^{43}$. Jego święto był zapewne obchodzone przynajmniej jako festum chori, a więc znane było przede wszystkim duchownym, i to tylko w wybranych ośrodkach, nie zaś w całej prowincji kościelnej. Miejsca związane z kultem św. Stanisława znajdują się przede wszystkim na północy kraju (zwłaszcza na terenie dzisiej-

40 Szczegóły dotyczące daty święta św. Stanisława w czeskich księgach liturgicznych i zestawienie źródeł oraz literatury zob. S. Kuzmová, Preaching Saint Stanislaus..., s. 104.

${ }^{41}$ Szczegóły na ten temat oraz zestawienie źródeł i literatury zob. S. Kuzmová, Preaching Saint Stanislaus..., s. 105-107.

42 Ibidem, s. 106; H. Wąsowicz, Kalendarz ksiag liturgicznych Krakowa do polowy 16. wieku. Studium chronologiczno-typologiczne, Lublin 1995, s. 370; H. Grotefend, Zeitrechnung des deutschen Mittelalters und der Neuzeit, Bd. 2, Abt. 2, Hannover 1898, s. 171; W. Schenk, op. cit., s. 32-33.

43 P. Radó, Libri liturgici manuscripti bibliothecarum Hungariae et limitopharum regionum, Budapest 1973, s. 17, tablica Festa pecularia Hungariae. Natomiast Jozef Kútnik zalicza Stanisława do świętych otoczonych szczególnym kultem w ramach wspólnego polsko-czesko-węgierskiego kręgu świętych, zob. idem, Dejiny kultu sv. Stanislava na Slovensku (Pro memoria) [w:] Svätec a jeho funkcie v spoločno$s t i$, vol. 2, red. R. Kožiak, J. Nemeš, Bratislava 2006, s. 323-332. 
szej Słowacji). Zapewne jest to wynikiem intensywniejszych kontaktów z sąsiednią Polską i pobliskim Krakowem. Dotyczy to zwłaszcza archidiecezji ostrzyhomskiej, spiskiej prepozytury i kapituły kolegiackiej w Bratysławie. Sporadycznie św. Stanisław był też czczony liturgicznie w innych miejscach (i to także „poza chórem”), w kościołach, których był patronem (o czym będzie mowa niżej).

Kult św. Stanisława funkcjonował w bardzo ograniczonym zakresie także w szeregu ośrodkach poza krajami sąsiadującymi z Polską. Wspominałam już wyżej przejawy kultu w Rzymie i w Asyżu. Ponadto liturgiczny kult św. Stanisława istniał do XVI wieku w klasztorze kanoników regularnych w Sankt Florian (w diecezji pasawskiej), niedaleko Linzu w Austrii. W 1325 roku wprowadzono tam obowiązek liturgicznego czczenia dnia męczeństwa i translacji św. Stanisława, którego relikwie zostały przywiezione najpewniej z Krakowa. Kanonikom regularnym zależało zapewne na pozyskaniu z Krakowa relikwii św. Floriana, rzymskiego żołnierza i męczennika, z którego męczeństwem legenda wiązała początki klasztoru, ale - jak przypuszczał Dobrowolski - zamiast Floriana otrzymali oni z katedry krakowskiej relikwie Stanisława ${ }^{44}$.

Kolejnym ośrodkiem kultu był w XV wieku Trydent. Tamtejszym biskupem został mianowany w 1423 roku przez papieża Marcina V Aleksander z mazowieckiej gałęzi Piastów, siostrzeniec króla Władysława Jagiełły. Dla objęcia stolicy biskupiej wjechał on 26 czerwca 1424 roku uroczyście do Trydentu wraz ze świtą, złożoną między innymi z Polaków, przywożąc z Polski relikwie św. Wojciecha i św. Stanisława. Następnie poprzez postanowienia synodalne z roku 1429 (lub z 1439) wprowadził święta św. Wojciecha, św. Stanisława i św. Jadwigi Śląskiej do kalendarza liturgicznego diecezji trydenckiej. Po śmierci biskupa Aleksandra w 1444 roku kult ten szybko zamar ${ }^{45}$.

\section{Wezwania kościołów, patrocinia}

$\mathrm{Na}$ Węgrzech w średniowieczu bardzo nieliczne kościoły były dedykowane św. Stanisławowi. Znajdowały się one w Pongrácovce, Miloj, Wielkim Szaryszu (Vel'ký Šariš, augustiański kościół) i Staré. Wszystkie były usytuowane na terenie dzisiejszej Słowacji, zwłaszcza na Spiszu i Szaryszu. Niektóre wezwania, podobnie zresztą jak i w Czechach, pochodzą z późniejszego okresu, zwłaszcza z czasów

44 Więcej na temat kultu św. Stanisława w Sankt Florian zob. K. Dobrow olski, op. cit., s. 116-133. Lokalny kalendarz określa święto 8 maja jako summum festum, zaś w XIV i XV w. jako minus summum festum. Święto translacji pojawia się tylko w kilku kalendarzach. Czternaście mszałów z Sankt Florian zawiera oficjum mszalne o św. Stanisławie, zaś jedenaście kodeksów - oficjum brewiarzowe i jeden kodeks zawiera kazanie o św. Stanisławie; na temat tego kazania zob. niżej przypis 60.

45 J.W. Woś, Un culte importe. Saint Adalbert et l'évêque de Trente Alexandre de Mazovie (14231444) [w:] idem, Adalbert et Stanislas, saints patrons de la Pologne, transl. A. de Penanster, Paris 1998, s. 97-108. Por. Kalendarz liturgiczny opublikowany w: A. Pilgram, Calendarium chronologicum medii potissimum aevi, Viennae 1781, s. 196. Zob. także K. Dobrowolski, op. cit., s. 120. 
kontrreformacji ${ }^{46}$. Prawdopodobnie impulsem do uczynienia ze św. Stanisława patrona kościołów w II połowie XIII wieku był udział niektórych z kościelnych dygnitarzy w uroczystościach kanonizacyjnych w Krakowie w 1254 roku. Jak już wspominałam, mogli oni tam otrzymać relikwie świętego, które były rozdawane rozmaitym instytucjom kościelnym. Niektóre z patrociniów mogły być wynikiem politycznych i kulturalnych kontaktów z Polską nawiązywanych wkrótce po kanonizacji. Przykładem może tu być wzmiankowana już wizyta Stefana V w Krakowie. Kościół we wsi Staré (w komitacie Zemplín), który od początku XIV wieku nosił compatrocinium św. Stanisława, był fundacją arystokratycznej rodziny Sztáray, która miała krewnych w okolicach Krakowa ${ }^{47}$. Tadeusz M. Trajdos uważa, że istnienie niektórych patrociniów św. Stanisława w północnej Słowacji wskazuje na jakiś rodzaj politycznej zależności tych terenów od polskich możnych lub obecności polskich wspólnot na tych terenach. Hipoteza ta jest jednak tylko jednym z możliwych wytłumaczeńn ${ }^{48}$. Na omawianym terenie znajdowało się ponadto kilka ołtarzy z wizerunkiem św. Stanisława ${ }^{49}$. W. Ryneś sporządził listę kościołów czeskich pod wezwaniem św. Stanisława, ale prawdopodobnie większość z nich nie pochodziła ze średniowiecza ${ }^{50}$.

\section{Hagiografia i rękopisy}

Obok już wspominanych śladów kultu nie można zapomnieć o dziełach hagiograficznych oraz pomocach kaznodziejskich dotyczących św. Stanisława. Łacińska legenda na święto męczeństwa św. Stanisława została dołączona do Złotej Legendy Jakuba z Voraginy zarówno w wersji rozpowszechnianej na ziemiach polskich, jak

46 J. Hudák, op. cit.; A. Mező, op. cit., s. 395-396. A. Mező wspomina jeszcze: Frydman, Nemecká Lupča, i Ružomberok. Kościoły z wezwaniem św. Stanisława spoza okresu średniowiecza znajdowały się w Opatovej nad Váhom, Podolińcu, Radošovcach (J. Hudák, op. cit., s. 263).

47 J. Hudák, op. cit., s. 337; A. Mező, op. cit., s. 396; J. Kútnik, Dejiny kultu sv. Stanislava na Slovensku (Pro memoria), s. 328.

48 T.M. Trajdos, Kult św. Stanisława na Spiszu [w:] Święty Stanisław patronem ładu spolecznego, red. B. Wójcik, Tarnów 2003, s. 73-89.

49 Dwa ołtarze (Pongrácovce i Frydman) wymienione są przez Edith Lajta: Trois scènes de la légende de St. Stanislas, „Bulletin du Musée Hongrois-des-Beaux-Arts” 1954, vol. 5, s. 29-35. D. Radocsay wymienia kilka ołtarzy czy tablic ołtarzowych ze św. Stanisławem głównie z XV i początku XVI w., które znajdują się w następujących miejscowościach: Spišská Sobota, Ilja (Hont), Kremná (Spisz), Koszyce (kościół św. Antoniego), Sabinov, Vel'ký Slavkov, Nemecká Lupča (D. Radocsay, A középkori Magyarország táblaképei, Budapest 1955, s. 448, 328, 277, 341, 355, 404, 410). Na temat ołtarza w Spišskiej Sobocie, jednym z miast spiskich zastawionych przez Zygmunta Luksemburskiego w 1412 r. Królestwu Polskiemu, która to zależność polityczna odegrała istotną rolę w wyborze patronów św. Floriana i św. Stanisława, obok głównego patrona św. Jerzego - zob. Gotika. Dejiny slovenského výtvarného umenia, red. D. Buran et al., Bratislava 2003, s. 423, 753-755.

50 W. Ryneś, Kult św. Stanisława biskupa w Czechach, „Zeszyty Naukowe KUL” 1978, t. 21, s. 76 (wymienia 11 miejscowości). Z. Jakubowski (op. cit., s. 66) podaje listę czterech kościołów, większość pochodzi z czasów przedhusyckich, ale wezwania św. Stanisława zostały nadane dopiero w czasach rekatolicyzacji. 
i w redakcji tego dzieła powstałej w Czechach ${ }^{51}$, a także w kopiach z terenów Królestwa Węgier (np. w rękopiśmiennych pasjonałach proweniencji czeskiej używanych w Bratysławie ${ }^{52}$ czy kodeksach proweniencji węgierskiej albo polskiej występujących na Spiszu ${ }^{53}$ ). W kompendium Złotej Legendy przeznaczonym dla Królestwa Węgier, które ukazało się w postaci druku jako Legende sanctorum regni Hungarie in Lombardica historia non contente (Strasburg 1483, Wenecja 1498, 1512), znalaz1 się także Żywot św. Stanisława ${ }^{54}$.

Istniały też dzieła o św. Stanisławie pisane w językach narodowych w końcu XV i początku XVI wieku. Nie zachowała się jednak żadna polska wersja żywota świętego $\mathrm{z}$ tego okresu. Łacińska legenda o św. Stanisławie została przetłumaczona na staroczeski i opublikowana przez Jana Kampa w 1495 roku w drugim, poprawionym wydaniu inkunabułowym staroczeskiego pasjonału ${ }^{55}$. Ponadto ta legenda została przełożona na język węgierski i w tej wersji znalazła się w rękopiśmiennej kolekcji hagiograficznej w kodeksie Érdy z 1526 roku $^{56}$.

51 Czternaście rękopisów zawiera tę legendę w kilku wersjach, zob. Jakub de Voragine, Legenda aurea, ed. i transl. A. Vidmanová, V. Bahník, Praha 1984, s. 53. W zbiorach czeskich znajdują się też egzemplarze skróconej wersji Żywota Tradunt św. Stanisława, która pomija wątki polityczne związane z odnowieniem Królestwa Polskiego. Zdaniem W. Drelicharza (op. cit., s. 316, 324) została ona zredagowana w Czechach w II połowie XIV w.

52 Na przykład kodeks zawierający Legenda aurea z XIV w., proweniencji czeskiej, używany przez kapitułę bratysławską (Budapest, Országos Széchenyi Könyvtár, Cod. Lat. 89, f. 181v-182r; Sopko II, nr 207). Rękopisy odnotowane przez J. Sopkę identyfikuje się wedle numerów, pod którymi trafiły one do jego inwentarzy: J. Sopko, Stredoveké latinské kódexy v slovenských knižniciach, vol. 1, Martin 1981; idem, Stredoveké latinské kódexy slovenskej proveniencie v Mad'arsku a Rumunsku, vol. 2, Martin 1982 (dalej cyt.: Sopko II).

${ }_{33}$ Kilka rękopisów używanych na Spiszu, które należały później do biblioteki w Lewoczy, obecnie w zbiorze Batthyaneum w Alba Iulia, zawiera różne wersje legendy o św. Stanisławie: kolekcja kazań z legendami o świętych z II połowy XV w. w rkpsie Alba Iulia, Batthyaneum, R I 79, f. 41r-47r, f. 59r60r (Sopko II, nr 325, s. 176); legenda w Spiskim brewiarzu D w rkps. R II 46, f. 310v-311v (Sopko II, nr 362, s. 214-215); legenda w Legenda aurea w rkps. R I 76 (Sopko II, nr 322, s. 173-174); legenda z kodeksu Legenda aurea z kazaniami, spisana w 1371 r. przez Piotra z Opola, kaznodzieję kościoła Mariackiego w Krakowie, a potem w Lewoczy w rkps. R II 101, f. 82v-83r (Sopko II, nr 391, s. 241); kolekcja Sermones cum vitis et legendis sanctorum datowana przed 1456, spiskiej proweniencji albo przyniesiona przez studenta z Krakowa w rkp. R I 154, f. 171r-173r (Sopko II, nr 337, s. 192-193). Na temat tych rękopisów i biblioteki w Lewoczy zob. także R. Szentiványi, Catalogus concinnus librorum manuscriptorum Bibliotecae Batthyányanae, Szeged 1958; E. Selecká Mârza, A Középkori Löcsei Könyvtár, Szeged 1997 (wcześniej wydane w serii: „Slovenské knižnice”, 9 - E. Selecká, Stredoveká levočská knižnica, Martin 1974).

${ }^{54}$ E. Madas, La Légende dorée - Historia Lombardica - en Hongrie [w:] Spiritualità e lettere nella cultura italiana e ungherese del basso medioevo, red. S. Graciotti, C. Vasoli, Firenze 1995, s. 53-61.

55 Jakub de Voragine, Legenda aurea, s. 62; facsimilowe wydanie: Kališnický pasionál z roku 1495, ed. Z. V Tobolka, Praha 1926 („Monumenta Bohemiae Typographica”, 2).

56 Opis katalogowy kodeksu dostępny na stronie Sermones compilati, http://sermones.elte.hu/ erdy/, gdzie Żywot św. Stanisława znajduje się pod nr 79. Stara edycja z XIX w.: Nyelvemléktár: Régi magyar kódexek és nyomtatványok, vol. 4, ed. G. Volf, Budapest 1874-1908, s. 427-436. Na ten temat: M.I. Tóth, Szent Szaniszló Magyarországi tisztelete és az Érdy-kódex Szent Szaniszló-legendája, http:// sermones.elte.hu/?az=319tan_plaus_tothmiklos. Źródłem była prawdopodobnie kolekcja Legendae sanctorum regni Hungariae in Lombardica Historia non contentae. 


\section{Kaznodziejstwo}

Kazania o św. Stanisławie zachowane w rękopisach są ważnym świadectwem jego kultu. Kazania o większości świętych powstawały zazwyczaj w miejscu ich pochodzenia, centrach i ośrodkach kultu, gdzie wspomnieniu danego świętego przyznana była najwyższa ranga liturgiczna, z której wynikał obowiązek głoszenia kazania.

Kazania o św. Stanisławie były głoszone nie tylko w Krakowie, czy szerzej w Polsce. Potwierdzają to zarówno proweniencja rękopisów kaznodziejskich, jak i omówione już wcześniej przepisy liturgiczne. Kazania o św. Stanisławie były kopiowane w tych miejscach, gdzie jego święto zyskało rangę festum fori. W innych przypadkach obecność kazań o św. Stanisławie wynikała raczej z obiegu rękopisów, a same kazania traktowane były jako przedmiot lektury, nie zaś pomoc kaznodziejska do głoszenia kazań na jego święto. W wielu przypadkach zatem obecność kazania w rękopisie przechowywanym poza granicami Polski nie oznacza, że takie kazanie było tam rzeczywiście głoszone. Niektóre z tych tekstów powstały w innym ośrodku (najczęściej w Polsce, gdzie kult św. Stanisława był żywy), a następnie przeszły do konkretnych miejsc razem z rękopisami, w których zostały umieszczone. W ten sposób na przykład kazania w kodeksach z Uppsali, proweniencji czeskiej albo niemieckiej, mogły być kopiowane w Pradze przez jakiegoś polskiego studenta na tamtejszym uniwersytecie ${ }^{57}$. Ważną rolę w rozpowszechnianiu rękopiśmiennych kolekcji kaznodziejskich - które czasami programowo, ale znacznie częściej przypadkiem zawierały również kazanie czy legendę o św. Stanisławie - odgrywały kontakty i podróże duchownych, zakonników, a także studentów i absolwentów uniwersytetów oraz „wymiana kadr” (ale i książek) między uniwersytetami (przede wszystkim w Pradze, Krakowie i Rzeszy Niemieckiej), a także handel tekstami i rękopisami w trakcie soborów powszechnych. Tymi drogami tekst kazania o św. Stanisławie trafiał czasem w miejsca, gdzie jego żywy kult nigdy nie istniał.

Wyjątkowe miejsce wśród kazań o św. Stanisławie głoszonych poza granicami ma kazanie z verba thematis Ego sum pastor bonus, które wygłosił Mikołaj z Kozłowa (ok. 1378-1443) na soborze w Bazylei, najprawdopodobniej w maju 1435 roku. Kazanie to zachowało się w kilku kopiach w polskich zbiorach rękopiśmiennych ${ }^{58}$. Ponadto tekst ten znalazł się poza granicami kraju, a to dzięki soborowym kontaktom. Fragment tego kazania, niestety pozbawiony części, w której znajdowały się konkretne wzmianki o polskim świętym, zawiera rękopis w Balliol College, gdzie trafił wraz z kolekcją kazań i tekstów soborowych przywiezioną z Włoch przez

57 Zob. rękopisy Uppsala, Universitetsbibliothek: C 201 z kazaniem Peregryna z Opola na f. 196v$198 \mathrm{v}$; C 324 z redakcją tego samego kazania na f. 88r-90r oraz C 383 z kazaniem anonimowym (nr LXX w katalogu zamieszczonym w pracy autorki); zob. S. Kuzmová, Preaching Saint Stanislaus..., s. 411-412.

58 Rkps Kraków, BJ 1614, f. 74v-80v; BJ 1354, s. 182-186; Gniezno, Archiwum Archidiecezjalne, Biblioteka Katedralna 15, f. 4r-11r. Na temat tego kazania zob.: S. Kuzmová, Preaching Saint Stanislaus..., s. 150-151, 175, 242-243, oraz pod nr VIII i VIIIB w Aneksie 1, ibidem, s. 342-343. 
biskupa Williama Greya ${ }^{59}$. Pierwsza część tego kazania, z kwestią na temat doskonałości duszpasterskiej, mogła być ciekawa dla odbiorców zainteresowanych reformą Kościoła w ogóle i nie jest wyrazem szczególnej czci dla św. Stanisława czy też zainteresowania się osobą polskiego świętego.

Kopiowanie kazań o św. Stanisławie poza Polską mogło również oznaczać, że uważano je za przydatne w praktyce kaznodziejskiej i duszpasterskiej. Były one także głoszone (dowodem są notatki w rękopisach) w miejscach, gdzie funkcjonował liturgiczny kult świętego, jak to zostało już wyżej stwierdzone. Dotyczy to przede wszystkim obszarów sąsiadujących z Polską i na przykład klasztoru w Sankt Flo$\operatorname{rian}^{60}$. W Europie Środkowej dużą popularnością cieszyło się przede wszystkim kazanie o św. Stanisławie pochodzące ze zbioru dominikanina Peregryna z Opola oraz jego redakcje, a obok niego były w obiegu pojedyncze kazania, znajdujące się zarówno w rękopisach przywiezionych z Polski, jak i kopiowanych poza Polską.

Kazanie Peregryna (z początku XIV w.) było najbardziej znanym kazaniem o św. Stanisławie ${ }^{61}$. Rozpowszechniło się ono na ziemiach czeskich już w połowie XIV wieku. Być może dotarło tam jeszcze wcześniej, najpewniej za pośrednictwem dominikanów w ramach polsko-czeskiej prowincji. Kilka rękopisów ze zbiorem Peregryna zawierających kazanie o Stanisławie znajduje się w Pradze ${ }^{62}$. Czeskie glosy w niektórych z tych kodeksów pozwalają z dużym prawdopodobieństwem uznać ich czeską proweniencję lub przynajmniej stwierdzić fakt ich używania przez czeskich kaznodziejów. Dowodem na to, że utwór Peregryna znany był na ziemiach czeskich, są również przykłady kazań, których autorzy najprawdopodobniej opierali się na tekście Peregryna, czerpiąc z niego dające się wyśledzić inspiracje ${ }^{63}$. Ponadto istniała redakcja kazania Peregryna w języku staroczeskim, zachowana w rękopisie z Dzikowa

59 Rkps Oksford, Balliol College 165a, s. 744-748, więcej o kazaniu zob. przypis poprzedni, o tym rękopisie zob. S. Kuzmová, Preaching Saint Stanislaus..., s. 417-418.

60 Rkps Sankt Florian, Stiftsbibliothek, XI. 262, f. 245v-246r: kazanie anonimowe (nr XVIII), zob. S. Kuzmová, Preaching Saint Stanislaus..., s. 417, edycja na s. 432-433. Kazanie mogło być spisane w klasztorze w Sankt Florian, ale losy rękopisu nie są dokładnie znane; zob. D. Wójcik-Zega, Twórczość kaznodziejska dominikanina Marcina Polaka († 1278), Kraków 2006 (maszynopis pracy doktorskiej w Archiwum Uniwersytetu Jagiellońskiego), s. 86-89.

${ }_{61}$ Na ten temat zob. S. Kuzmová, Preaching Saint Stanislaus..., s. 178-231; eadem, Recepcja kazania Peregryna z Opola o św. Stanisławie w kazaniach autorów późnego średniowiecza [w:] Mendykanci w średniowiecznym Krakowie, red. K. Ożóg, T. Gałuszka, A. Zajchowska, Kraków 2008, s. $425-458$.

62 Praga, Archiv Pražského hradu, Fond Metropolitní Kapitula u sv. Vita F 65/2, f. 46-48 i F 71, f. 207-209; Praga, Národní knihovna I F 5, f. 101v-102r i I H 17, f. 84r-85v; może także rękopis w Wiedniu, Österreichische Nationalbibliothek Cod. 14570, f. 114v-116r jest czeskiej proweniencji, zob. omówienie wymienionych rękopisów w: S. Kuzmová, Preaching Saint Stanislaus..., s. 185-186, 228, 412-414, 418-419.

${ }^{63}$ Czternastowieczne kazania - nr XXIV w rkps. Praga, Kapitulní knihovna, F 46, f. 80r (edycja w: S. Kuzmová, Preaching Saint Stanislaus..., na s. 433-434) i nr LXII w rkps. Bratislava, Slovenský národný archív, Kapitulná knižnica, 64, f. 327v, prawdopodobnie czeskiej proweniencji, zob. S. Kuzmová, Preaching Saint Stanislaus..., s. 228. Kolejne ślady znaleźć można w legendzie, która być może też jest oparta na hagiograficznej części kazania Peregryna w rękopisach ze zbiorów w Olomuńcu, zob. ibidem, s. 229-230. 
z 1420 roku, uważana niegdyś za zaginioną, a przechowywana obecnie w Bibliotece Jagiellońskiej $^{64}$. Również kodeks przechowywany obecnie w Uppsali zawierający kazanie śląskiego dominikanina o Stanisławie jest czeskiej albo niemieckiej proweniencji ${ }^{65}$. Poza Europą Środkową zbiór kazań Peregryna najczęściej kopiowany był bez kazania o św. Stanisławie i innych polskich świętych. Nie trafiło ono także do wersji drukowanych Sermones de sanctis w XV i na początku XVI wieku ${ }^{66}$, co pokazuje, że polski święty nie był powszechnie znany. Warto zauważyć, że w kazaniu z rękopisu erfurckich benedyktynów skryba wykorzystał modelowe kazanie Peregryna o św. Stanisławie, by przerobić je na kazanie o św. Bonifacym ${ }^{67}$. Świadczy to o tym, że najprawdopodobniej kult polskiego świętego nie istniał w erfurckim klasztorze, zaś modelowy tekst kazania o krakowskim biskupie męczenniku został zaadaptowany na inną okoliczność liturgiczną, to jest święto ku czci św. Bonifacego.

Obok kazania Peregryna poza granicami Polski funkcjonował też tekst o św. Stanisławie pochodzący ze zbioru kazań modelowych Jana Hieronima z Pragi (przed 1370-1440), czeskiego kapłana i kaznodziei Władysława Jagiełły, premonstratensa, a potem kameduły we Włoszech. Jego kolekcja kazań Exemplar salutis, napisana w 1409 roku, była popularna przede wszystkim na ziemiach polskich ${ }^{68}$. Poza bibliotekami w Krakowie, Wrocławiu i Warszawie kopia kolekcji jego kazań znajduje się

64 Rkps BJ Acc. 177/51 (z Dzikowa), transkrypcja tekstu kazania w: W. Wisłocki, Kazania niedzielne $i$ świateczne $w$ języku tacińskim i czeskim z początku XV w. podtug kodeksu biblioteki hr. Tarnowskich w Dzikowie [w:] Rozprawy i Sprawozdania z Posiedzeń Wydziału Filologicznego AU, t. 3, Kraków 1875, 3, s. 256-342, edycja kazania na s. 329-335 (nr 82); zob. S. Kuzmová, Preaching Saint Stanislaus..., s. 219-222. Być może część rękopisu była spisana przez skrybę z terenu Słowacji lub północnych Węgier.

65 Zob. przypis 57. Egzemplarz kazania Peregryna o Stanisławie w Lipsku, Universitätsbibliothek rkps. 442, f. 66r-68v. Pięć kopii zbioru Peregryna, które zawierają też kazanie o św. Stanisławie, znajduje się w Bayerische Staatsbibliothek w Monachium. Lista rękopisów w: S. Kuzmová, Preaching Saint Stanislaus..., s. 338 i 420, na podstawie Polonica w średniowiecznych rękopisach bibliotek monachijskich, oprac. J. Wolny, M. Markowski, Z. Kuksewicz, Wrocław 1969, z poprawką i uzupełnieniem.

${ }^{66}$ Wstep edytorski, oprac. A. Podsiad [w:] Peregrini de Opole Sermones de tempore et de sanctis, ed. R. Tatarzyński, Warszawa 1997, s. XXII-XXIII.

${ }^{67}$ Rkps Oksford, Bodleian Library, Hamilton 50, f. 211-213. Zob. S. Kuzmová, Preaching Saint Stanislaus..., s. 223-224, gdzie porównanie obu tekstów. J.B. Schneyer wymienia to kazanie w spisie treści kolekcji Peregryna de sanctis, cf. idem, Repertorium der lateinischen Sermones des Mittelalters für die Zeit von 1150-1350, vol. 4, Münster 1972, s. 560, nr 138: In festo sancti Bonifatii („In his verbis tria dicuntur... sed incarnationis Domini 755.”); zatem kazania o św. Stanisławie brakuje na jego liście.

${ }_{68}$ Szczegóły biograficzne na jego temat zob. J. Zathey, Hieronim Jan Silvanus z Pragi [w:] Polski stownik biograficzny, t. 9, Wrocław 1960-1961, s. 507-509; J. Bidlo, Čeští emigranti v době husitské a mnich Jeroným Pražský, „Časopis Musea království Českého” 1895, R. 69, s. 118-128, 232-265, 424-452, na temat Jana Hieronima zob. zwłaszcza s. 242-263. Wśród nowszych studiów najważniejsze miejsce zajmują prace specjalisty od Jana Hieronima, W.P. Hylanda: Abbot John-Jerome of Prague: Preaching and reform in Early Fifteenth-Century Poland, „Analecta Praemonstratensia” 2004, vol. 80, s. 5-42; i monografia pióra J. Stejskala, Podivuhodný př́běh Jana Jeronýma, Praha 2004. Na temat kolekcji Exemplar salutis, zob.: A. Brückner, Kazania średniowieczne, cz. 2 [w:] Rozprawy Akademii Umiejętności Wydziat Filozoficzny, t. 24, Kraków 1895, s. 355-359; S. Kuzmová, Preaching Saint Stanislaus..., s. 142-145. 
na przykład w rękopisie z Budapesztu, pochodzącym ze Spisza i będącym niegdyś własnością Jana, proboszcza z Lubice ${ }^{69}$.

Ciekawym przykładem kaznodziejstwa o Stanisławie poza Polską jest rękopis R I 154 z kolekcji Batthyaneum w Alba Iulia (Gyulafehérvár) w Rumunii. Zawiera on piętnastowieczną kolekcję żywotów świętych i kazań (Sermones cum vitis et legendis sanctorum), należał zaś do biblioteki w Lewoczy (dzisiejsza Słowacja). Rękopis ten został spisany przez studenta Uniwersytetu Krakowskiego i przywieziony na Spisz. W rękopisie znajdziemy dodatkowo informację, że jego kopista, a zarazem właściciel głosił kazania na podstawie zgromadzonych tam materiałów. Jedna $\mathrm{z}$ takich not znalazła się na końcu legendy św. Stanisława: „1457 predicavi”70. Możemy przypuszczać, że kaznodzieja głosił to kazanie gdzieś na terenie Spisza. Inne anonimowe kazanie o św. Stanisławie znajduje się w kodeksie złożonym ze składek kopiowanych przez nieznanego studenta częściowo w Krakowie, a częściowo na Spiszu. Rękopis ten był własnością Jana z Kieżmarku ${ }^{71}$. W XV wieku żywe kontakty z Krakowem, a szerzej z Polską, nawiązywane za pośrednictwem studentów Uniwersytetu Krakowskiego i duchowieństwa odegrały ważną rolę w rozwoju kultu i rozpowszechnianiu tekstów związanych ze św. Stanisławem ${ }^{72}$.

Świadectwem rozprzestrzenienia się kultu św. Stanisława poza granice polskich diecezji są księgi liturgiczne, kalendarze, wezwania kościołów i relikwie świętego zachowane głównie w krajach ościennych - w Czechach i w Królestwie Węgierskim. Wyjątkowo ślady kultu świętego biskupa znajdują się także w innych odleglejszych miejscach, takich jak klasztor Sankt Florian w Austrii, Rzym, Asyż i Trydent. Kult ten nigdy jednak nie zyskał wielkiej popularności w Europie i rozszerzał się przede wszystkim za pośrednictwem kontaktów osobistych, politycznych i kulturalnych.

69 Budapest, Eötvös Loránd Tudományegyetem, Egyetemi Könyvtár, Cod. Lat. 50, kazanie o św. Stanisławie na f. 316vb-317rb. Na temat rękopisu zob.: S. Kuzmová, Preaching Saint Stanislaus..., s. 414.

70 R. Szentiványi, Catalogus concinnus..., s. 81-82; J. Sopko, Stredoveké latinské kódexy 2, s. 192-193 (nr 337); E. Selecká Mârza, A Középkori Löcsei Könyvtár, nr 83; S. Kuzmová, Preaching Saint Stanislaus..., s. 176.

71 Budapest, Eötvös Loránd Tudományegyetem, Egyetemi Könyvtár, Cod. Lat. 75, f. 450r-451v; kazanie nr II w S. Kuzmová, Preaching Saint Stanislaus..., s. 340, 415.

72 Na temat dużego grona studentów z Królestwa Węgier na Uniwersytecie Krakowskim w latach 1440-1526 zob. np. M. Rekettyés, Stosunki polityczne i kulturalne polsko-węgierskie za Władysława Jagiellończyka, Wrocław 1999, s. 111-125. Przykładem studenta, który zapoznał się ze św. Stanisławem podczas studiów w Krakowie, jest magister Georgius Petri, medyk w Kelheim koło Ratyzbony, który w 1475 r. informował J. Długosza podczas dziękczynnej pielgrzymki o cudownym powrocie w Slawonii jego siostry z mężem z tureckiej niewoli za wstawiennictwen św. Stanisława. Jednak miracula spisane przez Długosza podają tylko dwa przypadki cudów związanych z Węgrami i Niemcami, zob. J. Długosz, Vita, s. 166, 179-180; A. Witkowska, Kulty pątnicze piętnastowiecznego Krakowa, Lublin 1984, s. 134 . 


\section{BIBLIOGRAFIA}

\section{Rękopisy}

Alba Iulia, Batthyaneum, R I 79, R II 46, R I 76, R II 101, R I 154.

Bratysława, Slovenský národný archív, Kapitulná knižnica, 64.

Budapest, Eötvös Loránd Tudományegyetem, Egyetemi Könyvtár Cod. Lat. 50, Cod. Lat. 75.

Budapest, Országos Széchenyi Könyvtár Cod. Lat. 89.

Gniezno, Archiwum Archidiecezjalne, Biblioteka Katedralna, 15.

Kraków, Biblioteka Jagiellońska, 1614, 1354, 4915, Acc. 177/51.

Kraków, Biblioteka XX Czartoryskich, 3793 II.

Lipsk, Universitätsbibliothek, 442.

Oksford, Balliol College, 165a.

Oksford, Bodleian Library, Hamilton, 50.

Paryż, Bibliothèque Nationale, Lat. 755.

Praga, Archiv Pražského hradu, Metropolitní Kapitulní knihovna u sv. Víta, F 46, F 65/2, F 71.

Praga, Národní knihovna, I F 5, I H 17.

Sankt Florian, Stiftsbibliothek, XI. 262.

Uppsala, Universitetsbibliothek, C 201, C 324, C 383.

Wiedeń, Österreichische Nationalbibliothek Cod. 14570.

\section{Źródła drukowane}

Bullarium Poloniae, ed. I. Sułkowska-Kuraś, S. Kuraś, [t.] 1: 1000-1342, Romae 1982.

Bullarium Franciscanum Romanorum pontificum constitutiones, epistolas, ac diplomata continens tribus ordinibus Minorum, Clarissarum, et Poenitentium a seraphico patriarcha sancto Francisco institutis concessa ab illorum exordio ad nostra usque tempora, t. 2, ed. J.H. Sbaralea, Romae 1761 (Ed. Porziuncola 1983).

Codex diplomaticus Ecclesiae Cathedralis necnon Dioeceseos Vilnensis, vol. 1: 1387-1507, wyd. J. Fijałek, W. Semkowicz, Kraków 1948.

Codex diplomaticus et epistolaris regni Bohemiae, vol. 5/1, ed. J. Šebánek, S. Dušková, Praha 1974.

Długosz Jan, Vita sanctissimi Stanislai, ed. I. Polkowski, Ż. Pauli [w:] Joannis Dlugossii Senioris Canonici Cracoviensis Opera omnia, t. 1, Kraków 1887, s. 1-181.

Editiones archivii et bibliothecae S. F. Metropolitani capituli Pragensis Opus XXIV, ed. A. Podlaha, Pragae 1931.

Ioannis Dlugossii Annales seu Cronicae incliti Regni Poloniae, liber 7-8, ed. D. Turkowska et al., Varsaviae 1975.

Jakub de Voragine, Legenda aurea, ed. i transl. A. Vidmanová, V. Bahník, Praha 1984. Katalogi biskupów krakowskich, wyd. J. Szymański, „Monumenta Poloniae Historica”, Series Nova, t. 10/2, Warszawa 1974.

Kodeks dyplomatyczny Katedry Krakowskiej św. Wacława, cz. 1, wyd. F. Piekosiński, Kraków 1874. 
Kronika Dzierzwy, wyd. K. Pawłowski, „Monumenta Poloniae Historica“, Series Nova, t. 15, Kraków 2013.

Kronika Marignolova, ed. J. Emler [w:] Fontes rerum Bohemicarum, vol. 3, ed. J. Emler, Praha 1878, s. 492-604.

Kronika Pulkavova, ed. J. Emler, J. Gebauer [w:] Fontes rerum Bohemicarum, vol. 5, ed. J. Emler, Praha 1893.

Kronika wielkopolska, wyd. B. Kürbis, „Monumenta Poloniae Historica”, Series Nova, t. 8, Warszawa 1970.

Letopisy české, ed. J. Emler [w:] Fontes rerum Bohemicarum, vol. 2, ed. J. Emler, Praha 1874.

Miracula sancti Stanislai, wyd. W. Kętrzyński, „Monumenta Poloniae Historica”, t. 4, Lwów 1884, s. 285-318.

Nyelvemléktár: Régi magyar kódexek és nyomtatványok, vol. 4, ed. G. Volf, Budapest 1874 1908.

Rocznik Traski, wyd. A. Bielowski, „Monumenta Poloniae Historica”, t. 2, Lwów 1872.

Vita b. Hrosnatae mart. Ord. Praem. [w:] Acta Sanctorum, Julii III, Antverpiae 1723, coll. 804-810.

Vita sancti Stanislai auctore Joanne Longino seu Dlugosso [w:] Acta Sanctorum, Maii II (Dies 7), Antwerpiae 1680, facsimile reprint Turnhout 1968, coll. 202-276.

Vita sancti Stanislai Cracoviensis episcopi (Vita maior) auctore fratre Vincentio de ordine fratrum praedicatorum, wyd. W. Kętrzyński „Monumenta Poloniae Historica”, t. 4, Lwów 1884, s. 319-438.

Život blahoslaveného Hroznaty [w:] Fontes rerum Bohemicarum, vol. 1, ed. J. Emler, Pragae 1873, s. 369-383.

\section{Opracowania}

Abraham W., Powstanie organizacji Kościoła łacińskiego na Rusi, Lwów 1904.

Banaszkiewicz J., „, Sicut corpus sancti Stanislai Deus reintegravit...”, „Novum” 1979, nr 4-5, s. 207-221.

Barciak A., Czechy a ziemie potudniowej Polski w XIII oraz poczatkach XIV w. Polityczno-ideologiczne problemy ekspansji czeskiej na ziemie potudniowej Polski, Katowice 1992.

Bidlo J., Čeští emigranti v době husitské a mnich Jeroným Pražský, „Časopis Musea království Českého" 1895, R. 69, s. 118-128, 232-265, 424-452.

Bogucka M., Bona Sforza, Warszawa 1998.

Borkowska U., Dynastia Jagiellonów w Polsce, Warszawa 2011.

Borkowska U., The Jagiellonians as Founders of Ecclesiastical Institutions in the Grand Duchy of Lithuania and Poland [w:] Die Jagiellonen. Kunst und Kultur einer europäischen Dynastie an der Wende zur Neuzeit, Hrsg. D. Popp, R. Suckale, Nürnberg 2002, s. $123-130$.

Borkowska U., Królewskie modlitewniki. Studium z kultury religijnej epoki Jagiellonów (XV i poczatek XVI wieku), Lublin 1999.

Brückner A., Kazania średniowieczne, cz. 2 [w:] Rozprawy Akademii Umiejętności Wydziat Filozoficzny, t. 24, Kraków 1895. 
Crossley P., Ara Patriae: St Stanislaus, the Jagiellonians and the Coronation Ordinal for Krakow Cathedral [w:] Künstlerische Wechselwirkungen in Mitteleuropa, Hrsg. J. Fajt, M. Horsch, Ostfildern 2005 („Studia Jagiellonica Lipsiensia” 1), s. 103-123.

David P., Un légendier romain du temps d'Innocent IV et d'Urbain IV, Paris 1936.

Dekański D.A., Początki zakonu dominikanów prowincji polsko-czeskiej, Gdańsk 1999.

Dobrowolski K., Kult św. Stanisława w St. Florian w średnich wiekach, „Rocznik Krakowski" 1923, t. 19, s. 116-133.

Dola K., Kult świętego Stanisława biskupa i męczennika a tradycje polskie na Ślasku, „Studia Teologiczno-Historyczne Śląska Opolskiego" 1979, t. 7, s. 245-260.

Drelicharz W., Idea zjednoczenia królestwa w średniowiecznym dziejopisarstwie polskim, Kraków 2012.

Gotika. Dejiny slovenského výtvarného umenia, red. D. Buran et al., Bratislava 2003.

Grotefend H., Zeitrechnung des deutschen Mittelalters und der Neuzeit, Bd. 2, T. 2, Hannover 1898.

Homza M., Svätá Kunigunda a Spiš [w:] Terra Scepusiensis: Stav bádania o dejinách Spiša, red. R. Gładkiewicz, M. Homza, Levoča-Wrocław 2003, s. 381-405.

Homza M., Včasnostredoveké dejiny Spiša [w:] Historia Scepusii, vol. 1, red. M. Homza, S.A. Sroka, Bratislava-Kraków 2009, s. 125-327.

Hudák J., Patrocíniá na Slovensku, Bratislava 1984.

Hyland W.P., Abbot John-Jerome of Prague: Preaching and reform in Early Fifteenth-Century Poland, ,Analecta Praemonstratensia” 2004, vol. 80, s. 5-42.

Jakubowski Z., Polityczne i kulturowe aspekty kultu biskupa krakowskiego Stanisława w Polsce i Czechach w średniowieczu, Częstochowa 1988.

Kališnický pasionál z roku 1495, ed. Z.V. Tobolka, Praha 1926 („Monumenta Bohemiae Typographica", 2).

Klaniczay G., Holy Rulers and Blessed Princesses: Dynastic Cults in Medieval Central Europe, Cambridge 2002.

Kochanowska-Reiche M., Ikonografia kanonizacyjna św. Stanisława biskupa, „Biuletyn Historii Sztuki i Kultury" 1987, R. 49, nr 1-2, s. 73-85.

Kochanow ska-Reiche M., Najstarsze cykle narracyjne z legendy św. Stanisława biskupa, „Ikonotheka. Prace Instytutu Historii Sztuki Uniwersytetu Warszawskiego” 1991, t. 3, s. $27-48$.

Kubín P., Blahoslavený Hroznata - Kritický životopis, Praha 2000.

Kult świętego Stanisława na Śląsu (1253-2003), red. A. Pobóg-Lenartowicz, Opole 2004.

Kurtyka J., Starostwo spiskie (1412-1769/70) [w:] Terra Scepusiensis: Stav bádania o dejinách Spiša, red. R. Gładkiewicz, M. Homza, Levoča-Wrocław 2003, s. 487-533.

Kútnik J., Dejiny kultu sv. Stanislava na Slovensku (Pro memoria) [w:] Svätec a jeho funkcie v spoločnosti, vol. 2, red. R. Kožiak, J. Nemeš, Bratislava 2006, s. 323-332.

Kuzmová S., Kazania o św. Stanisławie a hagiografia [w:] Kaznodziejstwo średniowieczne. Teksty, atrybucje, audytorium. Polska na tle Europy, red. K. Bracha, A. Dąbrówka, Warszawa 2014 („Colloquia Mediaevalia Praedicatoria”, t. 1), s. 69-84.

Kuzmová S., Preaching Saint Stanislaus: Medieval Sermons on St. Stanislaus of Cracow, His Image and Cult, Warszawa 2013.

Kuzmová S., Recepcja kazania Peregryna z Opola o św. Stanisławie w kazaniach autorów późnego średniowiecza [w:] Mendykanci w średniowiecznym Krakowie, red. K. Ożóg, T. Gałuszka, A. Zajchowska, Kraków 2008, s. 425-458. 
Labuda G., Święty Stanisław. Biskup krakowski, patron polski. Śladami zabójstwa - męczeństwa - kanonizacji, Poznań 2000.

Lajta E., Trois scènes de la légende de St. Stanislas, „Bulletin du Musée Hongrois-des-Beaux-Arts" 1954, vol. 5, s. 29-35.

Madas E., La Légende dorée - Historia Lombardica - en Hongrie [w:] Spiritualità e lettere nella cultura italiana e ungherese del basso medioevo, ed. S. Graciotti, C. Vasoli, Firenze 1995, s. 53-61.

Mező A., Patrocíniumok a középkori Magyarországon, Budapest 2003.

Mischke W., Pierwotny schemat ikonograficzny przedstawiania św. Stanistawa ze Szczepanowa: krakowski znak pielgrzymi z Czech i Moraw, „Ciechanowskie Studia Muzealne” 1990, t. 2, s. 37-68.

Mrozowicz W., Die politische Rolle des Kultes des hl. Adalbert, Stanislaus und der hl. Hedwig im Polen des 13. Jahrhunderts [w:] Fonctions sociales et politiques du culte des saints dans les sociétés de rite grec et latin au Moyen Âge et à l'epoque moderne: Approche comparative, éd. M. Derwich, M. Dmitriev, Wrocław 1999, s. 111-125.

Paciocco R., Canonizzazioni e culto dei santi nella christianitas (1198-1302), Assisi 2006.

Pauk M.R. Święci patroni a średniowieczne wspólnoty polityczne w Europie Środkowej [w:] Sacrum. Obraz i funkcja w spoteczeństwie średniowiecznym, red. J. Pysiak, A. Pieniądz-Skrzypczak, Warszawa 2005, s. 237-260.

Piech Z., Darstellungen des heiligen Stanislaus als Schutzheiligen des Herrschers, des Staates und der Dynastie der Jagiellonen [w:] Fonctions sociales et politiques du culte des saints dans les sociétés de rite grec et latin au Moyen Âge et à l'epoque moderne : Approche comparative, éd. M. Derwich, M. Dmitriev, Wrocław 1999, s. 125-159.

Pilgram A., Calendarium chronologicum medii potissimum aevi, Viennae 1781.

Plezia M., Dookoła sprawy świętego Stanisława, Bydgoszcz 1999.

Podlaha A., Šittler E., Chrámový poklad u sv. Vita v Praze, jeho dějiny a popis, Praha 1903.

Polonica w średniowiecznych rękopisach bibliotek monachijskich, oprac. J. Wolny, M. Markowski, Z. Kuksewicz, Wrocław 1969.

Radó P., Libri liturgici manuscripti bibliothecarum Hungariae et limitopharum regionum, Budapest 1973.

Radocsay D., A középkori Magyarország táblaképei, Budapest 1955.

Rajman J., Przedkanonizacyjny kult św. Stanisława, „Nasza Przeszłość” 1993, t. 80, s. 5-49.

Rekettyés M., Stosunki polityczne i kulturalne polsko-węgierskie za Wtadystawa Jagiellończyka, Wrocław 1999.

Rożnowska-Sadraei A., Jagiellonians and the Internationalisation of National Saints [w:] Image, Memory and Devotion: Liber Amicorum Paul Crossley, ed. Z. Opacić, A. Timmermam, Turnhout 2011, s. 265-274.

Rożnowska-Sadraei A., Pater Patriae: The Cult of Saint Stanislaus and the Patronage of Polish Kings 1200-1455, Kraków 2008.

Ryneś W., Kult św. Stanisława biskupa w Czechach, „Zeszyty Naukowe KUL” 1978, t. 21, s. 76-77.

Selecká Mârza E., A Középkori Löcsei Könyvtár, Szeged 1997.

Schenk W., Kult liturgiczny św. Stanisława biskupa na Ślasku w świetle średniowiecznych rękopisów liturgicznych, Lublin 1959.

Schneyer J.B., Repertorium der lateinischen Sermones des Mittelalters für die Zeit von 1150-1350, vol. 4, Münster 1972. 
Sobeczko H.J., Liturgia Katedry Wrocławskiej wedtug przedtrydenckiego „Liber Ordinarius” z 1563 roku (Opole, Archiwum Diecezjalne, rkps nr M 1), Opole 1993.

Sopko J., Stredoveké latinské kódexy slovenskej proveniencie v Mad'arsku a Rumunsku, vol. 2, Martin 1982.

Sopko J., Stredoveké latinské kódexy v slovenských knižniciach, vol. 1, Martin 1981.

Sroka S.A., Piastówny na Węrzech w dobie Jagiellonów (1490-1526) [w:] Ecclesia - cultura-potestas, red. P. Kras et al., Kraków 2006, s. 559-568.

Sroka S.A., Polacy na Wegrzech za panowania Zygmunta Luksemburskiego, 1387-1437, Kraków 2001.

Sroka S.A., Z dziejów stosunków polsko-węgierskich w późnym średniowieczu, Kraków 1995.

Starnawska M., Świętych życie po życiu. Relikwie $w$ kulturze religijnej na ziemiach polskich $w$ średniowieczu, Warszawa 2008.

Stej skal J., Podivuhodný př́běh Jana Jeronýma, Praha 2004.

Szakács B.Z., A Magyar Anjou Legendárium képi rendszerei, Budapest 2006.

Szentiványi R., Catalogus concinnus librorum manuscriptorum Bibliotecae Batthyányanae, Szeged 1958.

Śnieżyńska-S tolot E., Ze studiów nad ikonografią legendy św. Stanisława biskupa, „Folia Historiae Artium" 1972, t. 8, s. 161-183.

Tóth M.I., Szent Szaniszló Magyarországi tisztelete és az Érdy-kódex Szent Szaniszló-legendája, http://sermones.elte.hu/?az=319tan_plaus_tothmiklos [dostęp: 26.05.2018].

Trajdos T.M., Kult św. Stanisława na Spiszu [w:] Święty Stanisław patronem tadu społecznego, red. B. Wójcik, Tarnów 2003, s. 73-89.

Vauchez A., Sainthood in the Later Middle Ages, Cambridge 1997.

Walczak M., The Jagiellonian Saints: Some Political, National and Ecclesiastical Aspects of Artistic Propaganda in Jagiellonian Poland [w:] Die Jagiellonen. Kunst und Kultur einer europäischen Dynastie an der Wende zur Neuzeit, Hrsg. D. Popp, R. Suckale, Nürnberg 2002, s. 139-149.

Walczy Ł., Kazanie Jana ze Stupczy o św. Wojciechu - przyczynek do dziejów ideologii państwowej w drugiej połowie XV wieku, „Nasza Przeszłość” 1992, t. 77 s. 261-271.

Wąsowicz H., Kalendarz ksiag liturgicznych Krakowa do połowy 16. wieku. Studium chronologiczno-typologiczne, Lublin 1995.

Węcowski P., Strata korony królewskiej po śmierci św. Stanisława w opinii pisarzy późnego średniowiecza [w:] Christianitas Romana. Studia ofiarowane prof. Romanowi Michatowskiemu, red. K. Skwierczyński et al., Warszawa 2009, s. 274-299.

Witkowska A., Kulty patnicze piętnastowiecznego Krakowa, Lublin 1984.

Witkowska A., The thirteenth-century miracula of St. Stanislaus, Bishop of Krakow [w:] Procés de canonisation au Moyen Âge: Aspects juridiques et religieux, éd. G. Klaniczay, Rome 2004, s. 149-163.

Woś J.W., Un culte importe. Saint Adalbert et l'évêque de Trente Alexandre de Mazovie (1423-1444) [w:] idem, Adalbert et Stanislas, saints patrons de la Pologne, transl. A. de Penanster, Paris 1998, s. 97-108.

Wójcik-Zega D., Twórczość kaznodziejska dominikanina Marcina Polaka († 1278), Kraków 2006 (maszynopis pracy doktorskiej w Archiwum Uniwersytetu Jagiellońskiego).

Zathey J., Hieronim Jan Silvanus z Pragi [w:] Polski stownik biograficzny, t. 9, Wrocław 1960-1961, s. 507-509. 